\title{
SOME INEQUALITIES FOR EDGE LENGTHS AND CIRCUM-RADIUS OF A SIMPLEX IN HYPERBOLIC SPACE
}

\author{
YANG SHI-GUO, QI JI-BING AND SUN YU-TING
}

Abstract. For an $n$-dimensional simplex in hyperbolic space $H_{n}(-1)$ and spherical space $S_{n}(1)$, we establish some inequalities for its edge lengths and circum-radius.

Mathematics subject classification (2010): 51M10, 51M20, 52A20, 52A55.

Keywords and phrases: Circum-radius, edge lengths, hyperbolic simplex, inequality.

\section{REFERENCES}

[1] A. T. YAKUT, M. SAVAS, S. KADER, On the schlaflic differential formula based on edge lengths of tetrahedron in $H^{3}$ and $S^{3}$, Geom Dedicata, 138 (2009), 99-115.

[2] Y. CHO, Volume of a tetrahedron in terms of dihedral angles and circum-radius, Appl. Math. Lett., 18 (2000), 45-47.

[3] Y. CHо, H. Kiм, On the volume formula for hyperbolic tetrahedra, Discret. comput. Geom, 22 (1999), 347-366.

[4] D. A. Derevnin, A. D. Mednykh, M. G. Pashrevich, On volume of a symmetric tedrahedron in hyperbolic and spherical space, Siberian Math. J., 45 (2004), 840-848.

[5] J. Murakami, A. Ushigima, A volume formula for hyperbolic tedrahedra in terms of edge lengths, J. Geom., 83 (2005), 153-163.

[6] J. Murakami, M. Yano, On the volume of hyperbolic and spherical tetrahedron, Comm. Annal. Geom., 13 (2005), 379-400.

[7] B. KARHĞA, A. T. YAKUT, Vertex angles of a simplex in hyperbolic space $H^{n}$, Geom Dedicata, 120 (2006), 49-58.

[8] S. L. KollendorfF, Polar duality and the generalized law of sines, J. Geom., 86 (2006), 140-149.

[9] F. ERIKSSON, The law of sines for tetrahedra and n-simplices, Geom. Dedicata, 7 (1978), 71-80.

[10] L. M. Blumenthal, Theory and application of distance geometry, New York, 1953.

[11] D. S. Mitrinović, J. E. PeČArić And V. Volenec, Recent advances in Geometric Inequalities, Kluwer Academic, Dordrecht, Boston, London, 1989.

[12] YANG Lu, ZhANG Jing-ZhONG, The coverage radius of compact set in hyperbolic space, Science in China (Mathematics), 8 (1982): 802-806

[13] YANG Ding-HuA, Some new progress in the conditional extremum of the dihedral angles of simplex, Advances in Mathematics (China), 37 (2008), 6: 670-682.

[14] X. M. Mei, J. Zh. HuAng, Differential geometry, Higher Education Press, Beijing, 1988.

[15] E. B. VinberG, Geometry (II), Springer-Verlag, NewYork, 1993.

[16] Yang Lu, Zhang Jing-Zhong, Some metric problems in Non-Euclidean hyperbolic geometry I, Isogonal imbedding and metric equation, Journal of university of science and technology of China, mathematics album, 13 (1983), 5: 123-134. 